\title{
Malaysia-Thailand Cross Border Trade and Cross Border Special Economic Zone Potential: A Case Study of Rantau Panjang- Sungai Kolok Cross Border Town
}

\author{
${ }^{1}$ Abdul Rahim Anuar \& ${ }^{2}$ Azhar Harun \\ ${ }^{1}$ School of International Studies, Universiti Utara Malaysia, Malaysia \\ ${ }^{2}$ School of Government, Universiti Utara Malaysia, Malaysia \\ abd182@uum.edu.my; h.azhar@uum.edu.my \\ DOI: https://doi.org/10.32890/jis2018.14.8
}

Received: 4 January 2018

Revised: 15 June 2018

Accepted: 25 September 2018

\begin{abstract}
Towns along the Malaysia-Thailand border have always been associated with backwardness and being low-income regions. This is mainly because policy development in these border regions is based more on defence and security rather than economic considerations. Economic structures and cross-border trade towns of Sg. Kolok (Narathiwat, Southern Thailand) and Rantau Panjang (Kelantan, Malaysia) were examined with the objective to measure cross-border economic activity and the feasibility of establishing a Cross Border Special Economic Zone. Both towns are a shopping haven among local and foreign tourists, and have the potential to become a leading cross-border tourism product of the MalaysiaThailand border. The Malaysian government has also implemented the Eastern Corridor Economic Region to develop the East Coast region including Kelantan. Meanwhile, the Thailand Government has carried out the Southern Border Provinces Special Zone to develop its Southern region, including Narathiwat. With the security assurance in Southern Thailand coupled with both development plans being implemented, this may intensify economic activities in the towns of Rantau Panjang and Sg. Kolok. It was revealed that this has a spill-over effect in the border areas and the potential of creating a Cross Border Special Economic Zone at these border towns.
\end{abstract}

Keywords: Border trade, Cross border special economic zone, Rantau Panjang, Sg. Kolok.

\section{Introduction}

The objective of this study is to analyse the feasibility of cross border special economic zone (CB-SEZ) between the borders of Malaysia and Thailand, specifically in Rantau Panjang (Kelantan) and Sg. Kolok (Narathiwat). CB-SEZ will initiate development of Rantau Panjang and Sg. Kolok through increased trade flows and cross border investments 
as well as investments in Rantau Panjang-Sg. Kolok CB-SEZ. Consequently, this study will examine the economic fundamentals and comparative advantage in both areas with the aim of developing the CB-SEZ.

Adopting World Bank (2008) and Lord and Tangtrongita (2014) definition, a Special Economic Zone (SEZ) is generally defined as a geographically delimited area, usually physically secured (fenced-in) that has a single management and administration entity, provides special incentives and other benefits to companies located within the zone, and has a separate customs area to provide duty-free benefits and streamlined procedures. Incentives are often based on duty-free trade and the absence of exchange controls, the facilitation of licenses and other regulatory requirements, reduced corporate and valueadded tax obligations, and the elimination of local fees. Those benefits are intended to lower production costs for goods processed and manufactured within the area and thereby offer companies the opportunity to sell those goods at more competitive prices than if they were produced elsewhere in the host country. In most cases, an SEZ is structured as a PublicPrivate Partnership (PPP) in which the public sector provides some level of support such as infrastructure, equity investment, and soft loans or bond issues, while the private sector contributes toward capital investment, employment, and local and provincial economic growth.

Table 1 shows types of Special Economic Zones.

Table 1

Type of Special Economic Zones

\begin{tabular}{|c|c|c|c|c|c|}
\hline Types of & & & & & \\
\hline $\begin{array}{l}\text { Special } \\
\text { Economic } \\
\text { Zone }\end{array}$ & $\begin{array}{l}\text { Development } \\
\text { Objective }\end{array}$ & Size & $\begin{array}{l}\text { Typical } \\
\text { Location }\end{array}$ & $\begin{array}{l}\text { Eligible } \\
\text { Activity }\end{array}$ & Market \\
\hline
\end{tabular}

Free Trade

Zone

(Commercial

Free Zone

Traditional
Export
Processing
Zone

Support Trade

Size $<50$ hectares

Size $<100$

hectares; total area is designated as Export Processing Zone

\section{Export manufacturing}

$\begin{array}{ll}\text { Ports of } & \begin{array}{l}\text { Entreport and } \\ \text { Trade-related }\end{array} \\ \text { entry } & \begin{array}{l}\text { activities } \\ \text { action }\end{array}\end{array}$

Domestic, Re-export

None

$\begin{array}{ll}\begin{array}{ll}\text { Manufacturing, } \\ \text { other }\end{array} & \begin{array}{l}\text { Mostly } \\ \text { processing }\end{array}\end{array}$




\begin{tabular}{|c|c|c|c|c|c|}
\hline $\begin{array}{l}\text { Types of } \\
\text { Special } \\
\text { Economic } \\
\text { Zone }\end{array}$ & $\begin{array}{l}\text { Development } \\
\text { Objective }\end{array}$ & Size & $\begin{array}{l}\text { Typical } \\
\text { Location }\end{array}$ & $\begin{array}{l}\text { Eligible } \\
\text { Activity }\end{array}$ & Market \\
\hline $\begin{array}{l}\text { Hybrid Export } \\
\text { Processing } \\
\text { Zone }\end{array}$ & $\begin{array}{l}\text { Export } \\
\text { manufacturing }\end{array}$ & $\begin{array}{l}\text { Size }<100 \\
\text { hectares; only } \\
\text { part of the area } \\
\text { is designated as } \\
\text { Export Processing } \\
\text { Zone }\end{array}$ & None & $\begin{array}{l}\text { Manufacturing, } \\
\text { other } \\
\text { processing }\end{array}$ & $\begin{array}{l}\text { Export and } \\
\text { domestic } \\
\text { market }\end{array}$ \\
\hline Freeport & $\begin{array}{l}\text { Integrated } \\
\text { Development }\end{array}$ & Size $>100 \mathrm{~km}^{2}$ & None & Multi-use & $\begin{array}{l}\text { Domestic, } \\
\text { internal } \\
\text { and export } \\
\text { markets }\end{array}$ \\
\hline $\begin{array}{l}\text { Enterprise } \\
\text { Zone. Free } \\
\text { Zone }\end{array}$ & $\begin{array}{l}\text { Urban } \\
\text { revitalisation }\end{array}$ & Size $<50$ hectares & $\begin{array}{l}\text { Distressed } \\
\text { urban or } \\
\text { rural areas }\end{array}$ & Multi-use & Domestic \\
\hline $\begin{array}{l}\text { Single Factory } \\
\text { Export } \\
\text { Processing } \\
\text { Zone }\end{array}$ & $\begin{array}{l}\text { Export } \\
\text { manufacturing }\end{array}$ & $\begin{array}{l}\text { Designation } \\
\text { for individual } \\
\text { enterprises }\end{array}$ & $\begin{array}{l}\text { Country } \\
\text { wide }\end{array}$ & $\begin{array}{l}\text { Manufacturing, } \\
\text { other } \\
\text { processing }\end{array}$ & $\begin{array}{l}\text { Export } \\
\text { market }\end{array}$ \\
\hline
\end{tabular}

Source. World Bank (2008).

According to Lord and Tangtrongita (2014), an SBEZ generally refers to a geographic region located along an international border crossing that is designated as a bilateral project area targeting a range of activities, like infrastructure development, construction of transport and logistics hubs, and the overall facilitation of cross-border trade and investment. In some cases, it can include cross-border "sister city" pairing. The objective is to bolster economic development of a border area as part of a sub-regional development strategy.

The SBEZ operates under the same principles as the SEZ: (i) investors are allowed to import and export free of duties and exchange controls; (ii) licensing and other regulatory processes are facilitated; and (iii) firms are usually freed from paying Value Added Tax, corporate taxes, and local taxes. However, it encompasses a wider set of components that support physical connectivity in the form of transport, communications, and energy links, and soft infrastructure related to (a) governance (business laws and regulations affecting the facilitation of trade, investment and finance); (b) economic infrastructure (logistics facilities and systems, finance, and processing and storage facilities); and (c) social infrastructure (border towns, education and research systems, and social welfare and healthcare systems). The fairly broad range of soft and hard infrastructure needed in the common territory between the two countries requires close institutional collaboration for the joint planning 
and management of trans-boundary flows of goods and services as well as the movement of people (Lord and Tangtrongita, 2014).

A cross-border regional study in Asia was initiated by the Asian Development Bank (ADB) in 1992. ADB $(1998,2002,2007)$ has reviewed the impact of social projects, economics and physical infrastructure which was implemented on the borders of 6 countries; namely Kampuchea, China, Laos, Myanmar, Thailand and Vietnam. The region between the borders is called the Greater Mekong Sub region (GMS) due to the proximity of the transnational region to the Mekong River basin. ADB has made GMS as a project to transform the economy at the borders, with the goal of advancing the districts between the borders of developing countries in Asia.

GMS covers a natural economic area of 2.6 million $\mathrm{km}^{2}$ with a combined population of 326 million people. In 1992, the six countries had joined the sub regional cooperation program with the aim to strengthen economic ties between them with financial assistance from ADB. The GMS program assisted in the implementation of high priority projects in transportation, energy, telecommunications, environment, human capital development, tourism, trade, private investment and agriculture sectors. Programs and development projects in GMS focuses on five core strategies; which are to strengthen the relationship of infrastructure, facilitating trade, investment and cross-border tourism, enhancing private sector participation and competition, developing human capital, and protecting the environment while promoting sustainable use of shared natural resources.

GMS utilizes the economic corridor approach to accelerate the economic cooperation phase among the 6 countries. There are three main economic corridors that were implemented, namely: North-South Economic Corridor (NSEC), East-West Economic Corridor (EWEC), and Southern Economic Corridor (SEC). Among the three major corridor economies, the NSEC will play a critical role in providing access to Yunan and Northern Laos into central seaports. Potential market coverage will be broader with a network of roads from Singapore to Chiang Rai through Malaysia and from Kunming to Beijing. The ADB $(1988,2002,2007)$ study results show that the programs and development projects conducted at GMS since 1992 has had a positive impact on the sectors of transportation, energy, telecommunications, environment, human capital development, tourism, trade, and agriculture to the bordering countries along the Mekong River.

Similar to the ADB study, Arnold (2010) examined the transformation of the economic zone which is border-based in GMS. His research focused on the Mae Sot region of Thailand (which borders Myanmar) and Bavet in Kampuchea (neighbours to Vietnam). Most of his analysis focused on the development strategy assessment through trading which were implemented by ADB. He focused on four factors which may affect the economic development of cross-border territories, namely the global economy, government policy, private sector and labour mobility. He summarized the relationship between finance, 
government commitment and labour mobility as an important feature in determining the success of the economic zone development which is based on borders such as Mae Sot and Bavet.

At the borders of the Southeast Asian Nations, Maneepong and Wu (2004), Tsuneishi (2008), and Choen (2008) has conducted cross-border studies between Thailand and its neighbours; namely Malaysia, Myanmar, Laos, and Cambodia.

Maneepong and $\mathrm{Wu}$ (2004) studied the factors affecting the success of the bordering towns in Thailand by partaking Nongkhai town (Thailand) near Vientiane (Laos) and Sadao (Thailand) nearby Bukit Kayu Hitam (Malaysia). Nongkhai and Sadao towns were chosen as a case study of cross border economics. The development of the bordering towns of Nongkhai is funded by the Thai government under its development plan compared to Sadao whose economic development is market-driven. In other words, they seek to compare the success of regional development or border zone which is funded by the government to those with success determined by market power. The location of both borders - Nongkhai and Sadao - is strategic as both are on the main roads between Vietnam-Laos and MalaysiaSingapore. Nongkhai connects the north-south highways from Hanoi (Vietnam) to Vientiane (Laos) and Bangkok. Sadao also connects the Asian highway and the north-south highway from Malaysia to Singapore.

Maneepong and Wu (2004) further assessed the development success in Nongkhai and Sadao using secondary data related to the following aspects: economic growth and trade, social issues, and environmental issues. They found the economic performance in bordering towns influenced by market power is better off than government-funded areas. Additionally, bordering towns without government support plays an important role in promoting crossborder tourism industry. The tourism industry is an important source of foreign exchange earnings for Thailand and Malaysia. To further develop a cross-border economy that is more sustainable, they have suggested some specific steps to develop bordering regions, such as to empower the community and local authorities to determine the direction of the border region development, promoting the local industry in the bordering towns, expanding the market for the local industry, promoting border town tourism, increasing government investment in infrastructure, and improving the government delivery system to be more efficient in bordering areas.

Tsuneishi (2008) studied the development of economic zone border in Thailand with the focus on cross-border trade expansion and the establishment of a special economic zone border. His study examined individual movements specifically labour mobility and crossborder trade flows. He further examined where and how free economic zones are able to be developed and assessed the direction of Thailand's border economic zone development policy with neighbouring countries which was implemented in 2008. In context to ThailandMalaysia relations, Tsuneishi (2018) studied the cross-border trade via Sadao and Padang 
Besar in Sadao and Padang Besa in the Songkhla region, Betong in the Yala region, Sg. Kolok and Tak Bai in Narathiwat region. He found that there was a strong cross-border trade relationship between Thailand and Malaysia during the 2005-2007 study period.

Choen (2008) studied cross-border trade and commerce in Thailand with neighbouring countries; Malaysia, Myanmar, and Laos. There are 30 main cross-border checkpoints between Thailand and its neighbouring countries. There are three main inspection doors between Thailand-Myanmar, 13 inspection doors with Laos, six checkpoints with Kampuchea, and eight checkpoints with Malaysia. The objective of the study was to determine whether the neighbouring regions can be potentially developed as a special economic zone border.

In the context of cross-border trade between Malaysia-Thailand (which includes eight main border checkpoints), Choen's findings show that during the period of 1996-2007, the cross border trade was generally in favour of Thailand. In 2007, the Malaysia-Thailand cross border trade value was worth 180 billion Baht which accounted for almost $45 \%$ of the total cross-border trade between Thailand and its' five neighbouring countries. Hatyai, Sadao and Sg. Kolok is a popular gateway for vacations or cross-border purchases for Malaysians and Singaporeans in comparison to other border doors in Thailand-Malaysia. Other border checkpoints - Padang Besar, Tak Bai, Betong, Wang Prachan, and Satun - played a bigger role as the location for retail trading among consumers or residents which settled on the respective borders. In terms of cross border trade, majority of products exported by Thailand to Malaysia are products from the southern Thailand region. Traders and merchants regard Sadao as a major trading route as Sadao is located on the path which links Bukit Kayu Hitam town and consequently Penang, Kuala Lumpur and Singapore. Choen (2018) further explained, the district of Sadao can be potentially developed as a free special economic zone. Industries that can be developed in related zones includes resource-based industries and electrical and electronic industries.

Meanwhile, Abdul Rahim, Muszafarshah and Amel (2013) and Abdul Rahim (2015) had studied the cross-border areas between Malaysia-Southern Thailand, and -Indonesia respectively. Abdul Rahim, Muszafarshah and Amel (2014) have studied the twin borders town, namely Danok (Thailand) and Bukit Kayu Hitam (Malaysia) with the aim of promoting Danok-Bukit Kayu Hitam as a special economic zone border through an interscalar modelization approach which analyses cross-border spatial organization between DanokBukit Kayu Hitam. The reason behind this is because Danok and Bukit Kayu is located on a strategic highway network from Bangkok to Danok-Bukit Kayu Hitam which became the gateway to Penang, Kuala Lumpur and Singapore through the North-South Expressway in Peninsular Malaysia. Logistics has become the major industry in Bukit Kayu Hitam industrial estate in comparison to manufacturing. According to Abdul Rahim et al. (2014), tourists from Malaysia and Singapore has helped shaped Sadao as a cross-border tourist hub. For residents of Sadao, industrial activities in the Bukit Kayu Hitam industrial estate and 
rubber fields provide employment opportunities to Thai labourers and simultaneously as a source of cheap labour to the industry at Bukit Kayu Hitam and Kubang Pasu. Meanwhile, Bukit Kayu Hitam town is the centre of security administration on the borders of Southern Thailand and the focus of logistics services industry in Bukit Kayu Hitam industrial estate. As a conclusion, their findings show that the twin town can potentially be developed as a special economic zone border based on their respective comparative advantages which complement each other despite the different economic fundamentals.

Abdul Rahim (2015) has also examined the reliability of the economic corridor between Malaysia and Indonesia borders, especially in Tawau (Sabah) and Nunukan (East Kalimantan). Both districts are under developed. The development concept in the borders of Malaysia-Indonesia remained conventional. Therefore, investments in the bordering areas through government and private initiatives is required to generate cross-border economic activity. The reason for this is because the towns of Tawau and Nunukan is the main entrance to the Malaysian market for residents in East Kalimantan and the Southern Philippines and vice versa for the people of Sabah. Abdul Rahim (2015) has proposed a development rubric in the perimeter town that takes into account the economic fundamentals and comparative advantages in Tawau and Nunukan. This implies the development of the Tawau-Nunukan cross-border economic corridor need to take into account the Sabah Development Corridor (SCORE) development plan, BIMP-EAGA and the Malaysia-Indonesia Socio-Economic (Sosek Malindo) Committee. The proposed development project in the cross-border economy corridor will have an overwhelming impact on economic development to the less developed region of Tawau and Nunukan by providing business and employment opportunities. In addition, trade relations and investments between East Kalimantan and Sabah which has been established for hundreds of years can be confirmed again through a forum on safety, economics, social and geopolitical cooperation between the Malaysian and Indonesian governments.

All these researchers emphasised the importance of establishing the CBSEZ to facilitate the growth of border regions. Developments in border regions that are remotely located are usually slow and stagnant. These border regions can be developed by enhancing the business supply chain, trade and investment connectivity through the CBSEZ. In relation to this, this article discusses the potential of developing the Rantau Panjang-Sg. Kolok CBEZ in the border area between Kelantan (Malaysia) and Narathiwat (Southern Thailand).

The border towns of Rantau Panjang (Kelantan) and Sg. Kolok (Narathiwat) are one of eight sister cross-border towns between Malaysia and Thailand. Malaysia shares maritime and land borders with Thailand. The northern states in Peninsular Malaysia, which includes Perlis, Kedah, Perak and Kelantan, share border lines via land and rivers with the southern regions of Satun, Songkhla, Yala, and Narathiwat in Thailand. The length of the MalaysiaThailand border from east to west is approximately $656 \mathrm{~km}$. Of the total distance, $551 \mathrm{~km}$ forms the land boundary, while $105 \mathrm{~km}$ forms the river boundary, which includes $\mathrm{Sg}$. Kolok, 
Kelantan. The twin border towns of Malaysia-Thailand that are next to each other include (i) Wang Kelian (Perlis)-Wang Prachan (Satun,Thailand), (ii) Padang Besar (Perlis)-Padang Besa (Songkhla, Thailand), (iii) Bukit Kayu Hitam (Kedah)-Danok (Songkhla, Thailand), (iv) Durian Burong (Kedah)-Ban Prakob (Songkhla, Thailand), (v) Pengkalan Hulu (Perak)Betong (Yala, Thailand), (vi) Bukit Bunga (Kelantan)-Ban Buketa (Narathiwat, Thailand), and (vii) Pengkalan Kubur (Kelantan)-Tak Bai (Narathiwat, Thailand).

Methods

This study is characteristically a case study and uses scoping analysis to discuss the feasibility of establishing the Rantau Panjang (Kelantan / Malaysia)-Sg. Kolok (Narathiwat / Thailand) CBSEZ. Figure 1 shows the location of Kelantan (Malaysia), Narathiwat (Thailand), and the borders towns of Rantau Panjang (Kelantan) and Sg. Kolok (Narathiwat), both of which are involved in this research.

Based on the definition of Escalada (2009), and Arksey and O'Malley (2005), scoping analysis is an approach to evaluate a research issue that has not been examined comprehensively. Scoping analysis will determine the degree of magnitude, seriousness, and intensity of the issue is being studied. This is done by reviewing the literature and reports related to the issue, collecting historical and up-to-date data to review the impact of its implementation, understanding the issues arising and developing an integrated strategy based on strengths, weaknesses, opportunities, and threats analysis to address these issues.
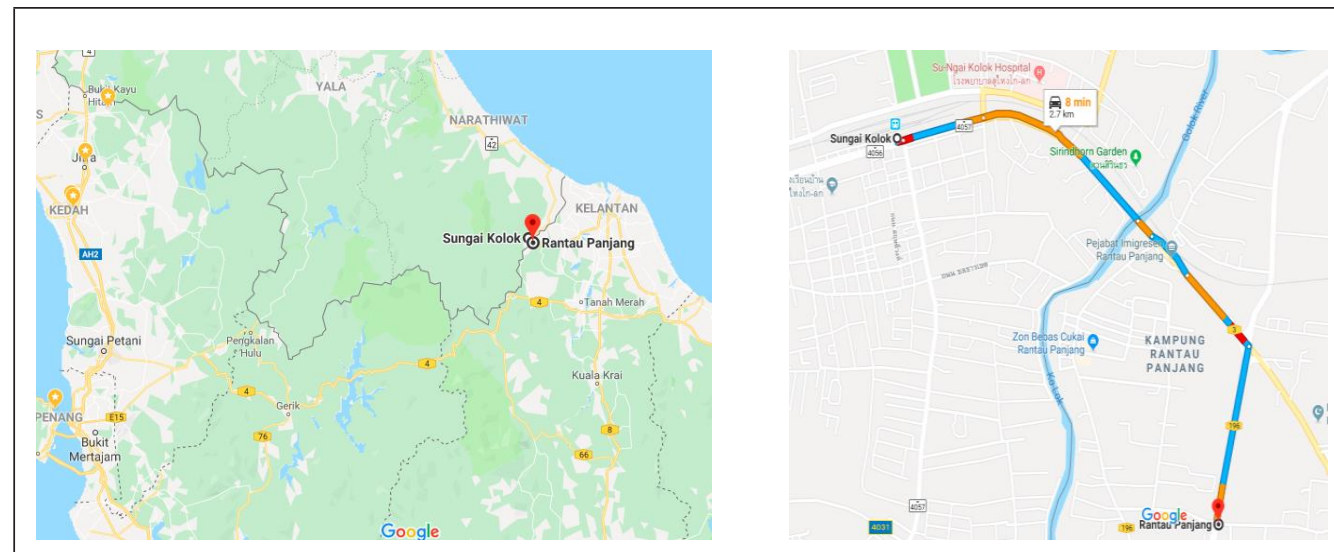

Figure 1. Location of Kelantan (Malaysia) and Narathiwat (Thailand), as well as the border towns of Rantau Panjang (Kelantan) and Sg. Kolok (Narathiwat).

Source. Google Map. 
Scoping analysis in this study was based on secondary data and development plan reports on border areas issued by the implementing agencies in the border region. Secondary data involved in this study included trade, investment, and tourism data. Interviews with implementing agency officials in border administration were also conducted. Questions submitted to the implementing agency were related to regional development strategy and territorial governance strategies. Activity observation at the location of the study was also conducted, especially in Sg. Kolok (Narathiwat) and Rantau Panjang (Kelantan), to observe the current economic development at these border regions.

Secondary data were obtained from publication and information supplied by agencies responsible for the administration of the boundary areas in Thailand and Malaysia. These agencies in Malaysia include Department of Statistics Malaysia, Royal Malaysia Customs Department, Immigration Department of Malaysia, and Pasir Mas District Office. Meanwhile, the agencies in Southern Thailand include Sungai Kolok Municipality Office, Sungai Kolok Customs House, Narathiwat, Thailand, Sungai Kolok Immigration Checkpoint, Sungai Kolok, Narathiwat, Thailand, and National Statistical Office, Songhkla, Thailand.

The duration of this study was from 2007 to 2018. Some data sources were limited, and the latest information cannot be obtained, such as the cross-border trade data which covered during the period of 2007-2013. Information were not obtainable due to the related agencies being tied to the certain privacy Acts, such as the Official Secrets Act 1972. However, this limitation does not hinder the researchers from analysing the feasibility of establishing the Rantau Panjang-Sg. Kolok CBSEZ.

\section{Results}

The results of the feasibility study for the establishment of Rantau Panjang-Sg. Kolok CBSEZ can be divided into three aspects, namely (i) Rantau Panjang-Sg. Kolok cross border trade activities, (ii) Kelantan's industrial estates and economic clusters, and (iii) Narathiwat Special Economic Zone (Thailand).

\section{Rantau Panjang-Sg. Kolok Cross Border Trade Activities}

Trade value reflects the economic activity acceleration between the two trading regions. Table 2 shows Malaysia's export value to Thailand and Malaysia imports from Thailand through Rantau Panjang CIQ for the period 2007-2013. The balance of trade (BoT) trend between Malaysia and Thailand was negative, except for 2013. This shows that cross-border trade is favourable for Thailand. 
Table 2

Value of Malaysia Export and Import with Thailand (RM million)

\begin{tabular}{ccccc}
\hline Year & $\begin{array}{c}\text { Export to } \\
\text { Thailand }\end{array}$ & $\begin{array}{c}\text { Import from } \\
\text { Thailand }\end{array}$ & $\begin{array}{c}\text { Trade } \\
\text { Balance }\end{array}$ & $\begin{array}{c}\text { Total } \\
\text { Trade }\end{array}$ \\
\hline 2007 & 54 & 183 & $(129)$ & 237 \\
2008 & 67 & 169 & $(102)$ & 236 \\
2009 & 78 & 194 & $(115)$ & 272 \\
2010 & 82 & 202 & $(121)$ & 284 \\
2011 & 117 & 206 & $(89)$ & 322 \\
2012 & 151 & 213 & $(62)$ & 364 \\
2013 & 248 & 204 & 44 & 453 \\
\hline
\end{tabular}

Source. Royal Malaysian Customs Department, Kelantan.

Although cross-border BoT is observed to be not profitable for Malaysia, total trade shows the intensification of cross-border trade between Kelantan and Narathiwat through Rantau Panjang-Sg. Kolok CIQs. This is illustrated by the total trade trend rising from RM237 billion (2007) to RM453 million (2013), nearly a doubling increase over the six years. Most products imported from Narathiwat are for the market in the Rantau Panjang DFZ in particular and also for markets in the east coast states of Peninsular Malaysia (Kelantan, Terengganu, and Pahang) in general. The intensification of cross-border trading activities becomes the basis for the establishment of Rantau Panjang-Sg. Kolok CBSEZ.

\section{Rantau Panjang Duty Free Zone}

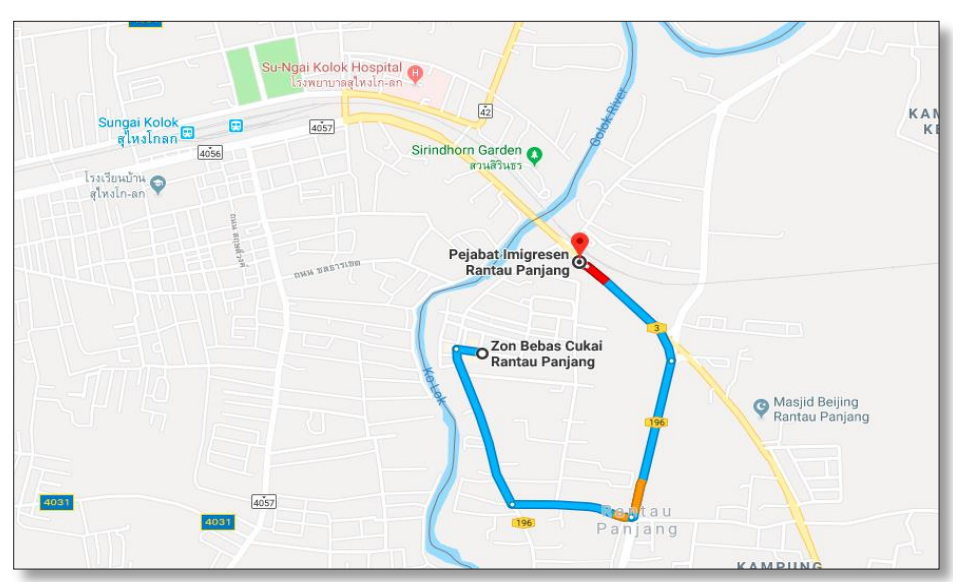

Figure 2. Location of Rantau Panjang Duty Free Zone in Kelantan.

Source. Google Map. 
The town of Rantau Panjang was declared a Duty Free Zone (DFZ) in 2002, which covers a one-hectare land area. Rantau Panjang is located approximately $40 \mathrm{~km}$ from Kota Bharu. Duty Free Shops (DFS) at DFZ Rantau Panjang are licensed premises that are allowed to store and sell duty free goods to qualified buyers. They were established under Section 65D of the Customs Act 1967 to cater to the necessities and requirements of international tourists (Royal Malaysian Customs Department, 2018). The shopping complex is open from 10.00 am to $7.00 \mathrm{pm}$. Figure 2 shows the location of Rantau Panjang DFZ near the boundary of Rantau Panjang-Sg. Kolok CIQs (Narathiwat) and Rantau Panjang CIQ.

Other than the DFS in Rantau Panjang, there are also DFS in other locations, namely:

- International Airports such as Kuala Lumpur International Airport (KLIA) Sepang, Bayan Lepas International Airport (Pulau Pinang), Kota Kinabalu International Airport (Sabah), and Kuching International Airport (Sarawak);

- $\quad$ Ports such as Port Klang (Selangor), Tanjung Belungkor (Johor), and Pengkalan Kubor (Kelantan);

- $\quad$ Cities such as Kuala Lumpur, Johor Baharu, Penang, Melaka, and Kuching;

- Border stations such as Padang Besar (Perlis), Bukit Kayu Hitam (Kedah), Pengkalan Hulu (Perak), Rantau Panjang (Kelantan) and Kuala Baram (Sarawak); and

- $\quad$ Padang Besar Railway Station, Perlis.

It was reported that there are 1,887 traders in Rantau Panjang DFZ (Fauzi et al., 2012). According to the Customs Duty Order (1988) and the Free Zones Act (1990), all goods purchased within the DFZ that are not for trading purposes are subject to a tax rate of $10 \%$. The types of goods sold by traders in the Rantau Panjang DFZ are electronic equipment, clothing, and kitchen utensils, and they can be bought at cheap and affordable prices. This has encouraged many local and international tourists to visit Rantau Panjang DFZ. There are 12 stores that supply imported goods in Rantau Panjang DFZ, as listed in Table 3.

Table 3

Companies that Supply Imported Goods in the Rantau Panjang Duty Free Zone

\begin{tabular}{cll}
\hline \multicolumn{1}{c}{ Company } & \multicolumn{1}{c}{ Types of Product } \\
\hline 1. & Jasa Duty Free & Chocolate, Liquor, Crockery, Perfume \\
2. & Chop Tong Hing & Pen and watch \\
3. & Sin HW Trading & Watch and Camera \\
4. & Sin Chong and Sales & Electrical product \\
5. & Wong Fock Siang & Electrical product \\
6. & Koleksi Nadi & Crystal and Apparel \\
7. & Syarikat Wong Brothers & Carpet \\
\hline
\end{tabular}

(continued) 


\begin{tabular}{rll}
\hline \multicolumn{1}{c}{ Company } & \multicolumn{1}{c}{ Types of Product } \\
\hline 8. & Sai Karpet & Carpet and Textile \\
9. & Chop Hock Suan & Chocolate \\
10. & Syarikat Niaga Jaya & Crockery \\
11. & ATP Sale Trading & Crockery \\
12. & Minotex Malaysia Sdn Bhd & Crockery \\
\hline
\end{tabular}

Source. Pasir Mas District Office, Kelantan.

\section{Tourism Industry}

Based on the the finding of Pasir Mas District Office (2008) on 140 local tourists and 60 international tourists visiting Pasir Mas., about $20 \%$ of the total number of local tourists and $10 \%$ of international tourists tend to visit Rantau Panjang DFZ. The average tourist spending by each tourist in 2008 was RM362.00 per day.

Table 4 shows the influx of local and international tourists to Kelantan for the period 19852015. On average, almost $95 \%$ of international tourists to Kelantan were from Thailand, particularly from Narathiwat. This is because, historically, the people in Narathiwat have long community relationships with the people in Kelantan.

Table 4

Local and International Tourist Data in Kelantan

\begin{tabular}{cccc}
\hline Year & Local Tourist & International Tourist & \multicolumn{1}{c}{ Total } \\
\hline 1985 & 220,012 & 27,000 & 247,012 \\
1990 & 557,225 & 126,148 & 683,403 \\
1995 & $1,209,170$ & 391,873 & $1,601,043$ \\
2000 & $2,235,024$ & 527,969 & $2,762,993$ \\
$2010^{\text {a }}$ & $4,464,017$ & 922,073 & $5,386,090$ \\
$2015^{\text {b }}$ & 384,866 & 111,244 & 496,110 \\
\hline
\end{tabular}

Note:

a - 2010 data were taken from 2010 Kelantan Tourist Arrival Statistics <http://www.kelantan.gov.my/index. $\mathrm{php} / \mathrm{ms} / \mathrm{media} /$ data-terbuka-kerajaan>

b - 2015 data were taken from UPEN (2018). 2015/16 Basic Economic Data.

Source. Kelantan State Tourism Information Centre (2000).

UPEN (2018).

In $2015,496,110$ tourists visited the state of Kelantan with local tourist making up $78 \%$ (384,866 people) and the rest $22 \%$ (111,244 people) were international travellers. Based on the ratio of shopping trends in the Rantau Panjang DFZ of $10 \%$ (international tourists) and 
20\% (local tourists), about 11,124 local tourists visited Rantau Panjang DFZ, while 38,487 local tourists visited the DFZ.

Based on the average daily spending per tourist of RM362.00, the total spending by tourists in Rantau Panjang DFZ (which is estimated at 49,611 tourists) is close to RM18 million per day. This high spending amount will generate retail and wholesale economic activities in Rantau Panjang DFZ. The rapid economic activity in this DFZ can be among the enablers for the establishment of Rantau Panjang-Sg. Kolok CBSEZ.

The tourism activity in the Rantau Panjang DFZ will contribute to the Royal Malaysian Customs Department (Kelantan) in the form of tax collected on goods exiting the Rantau Panjang DFZ. Based on the $10 \%$ tax rate imposed by the Royal Malaysian Customs Department, the agency can expect to receive tax revenue of RM1.8 million per day.

Table 5 shows the collection of tax revenue in Rantau Panjang DFZ for the period 2007-2011. Tax revenue collected by the Royal Malaysian Customs Department (Kelantan) depends on the visitors or tourists who buy in the Rantau Panjang DFZ. All goods purchased in the DFZ which are not trading purposes are subject to a tax rate of $10 \%$. The tax revenue collected by the Royal Malaysian Customs Department (Kelantan) shows an increasing trend.

Table 5

Collected Tax Revenue from Rantau Panjang DFZ, 2007-11

\begin{tabular}{cc}
\hline Year & Tax Revenue (RM millions) \\
\hline 2007 & 0.34 \\
2008 & 0.39 \\
2009 & 0.33 \\
2010 & 0.41 \\
2011 & 0.26 \\
\hline
\end{tabular}

Source. Royal Malaysian Customs Department, Kelantan.

\section{Cross Border Tourism}

The growth of the tourism industry in Kelantan has pushed the East Coast Economic Region Development Council (ECERDC) to develop Rantau Panjang as one of the centres of the Cross Border Tourism Corridor with Pengkalan Kubor and Bukit Bunga, which are in proximity to the Narathiwat border (Thailand).

Kelantan's proximity with neighbouring Thailand has made it a strategic gateway for crossborder tourism and commerce for decades. Cross-border tourism is expected to play an important role toward improving economic activities that have already existed at several 
towns on the Malaysia-Thailand border in Kelantan. Towns such as Pengkalan Kubor have long attracted a steady stream of domestic tourists in search of affordable imported goods from Thailand and Indo-China countries. Improving the prospects of cross-border tourism can be done by maximising the border town's potential as a tourist and excursionist gateway. From its current image as the destination for cheap, bargain goods, towns such as Rantau Panjang as well as Pengkalan Kubor and Bukit Bunga are expected to be transformed into integrated, modern destinations for shopping, dining, and recreation. Investors can capitalise on the lucrative cross-border trade by developing mass-market retail outlets focusing on duty-free goods (ECERDC, 2018).

\section{Industrial Estates and Economic Clusters}

The latest Industrial estate in Kelantan is Pasir Mas Halal Park in Pasir Mas and Tok Bali Industrial Park in Pasir Puteh, which are being developed by the East Coast Economic Region Development Council (ECERDC) in collaboration with the Kelantan State Economic Development Corporation (PKINK). There are also old indigenous estates developed by PKINK in the 1990s at Pengkalan Chepa, Gua Musang, Jeli, Tanah Merah, and Kemubu. Meanwhile, the industrial estate in Lundang was developed by the Malaysian Industrial Estate Limited (MIEL).

Table 6

Industrial Estates in Kelantan

\begin{tabular}{lc}
\hline \multicolumn{1}{c}{ Industrial Estate } & Area (Hectares) \\
\hline Pengkalan Chepa I & 9 \\
Pengkalan Chepa II & 119 \\
Gua Musang & 148 \\
Jeli & 36 \\
Tanah Merah & 78 \\
Kemubu & 28 \\
Lundang & 7 \\
Tok Bali & 81 \\
Pasir Mas Halal Park & 55 \\
\hline
\end{tabular}

Source. Kelantan State Economic Development Corporation (PKINK).

\section{Tok Bali Industrial Park}

There are two projects under the Tok Bali Industrial Park (TBIP), namely Tok Bali Integrated Fisheries Park (TBIFP) and the Tok Bali Supply Base (TBSB). The focus of economic activities in the TBIP covers manufacturing, agribusiness, and oil and gas (O\&G) sectors. 
TBIFP is expected to propel Tok Bali as the main fisheries hub for both local and export markets, reinforcing its potential to draw private investments in the primary processing of fish-based products, otoshimi, fishmeal, and supporting industries such as ice-making factories, with the integration of marine eco-tourism and hospitality sectors. Meanwhile, TBSB, Malaysia's third O\&G supply base, which is developed through a private initiative, is providing support services to the offshore O\&G industry for the development of offshore petroleum and gas in the north-eastern coast of Peninsular Malaysia (New Straits Time 2017, February 7).

\section{Pengkalan Kubor's Collection, Processing, and Packaging Centre}

Aside from the TBIFP project, the Collection, Processing, and Packaging Centre (CPPC) project is also developed in Pengkalan Kubur that is located close to the Thailand border, which is Tak Bai. The CPPC, the first of its kind in Malaysia, is targeted to produce up to 82,000 litres of premium fish sauce and is located in a major fish landing area. The centre is designed to comply with international standards for export markets. Kelantan Fishermen Association ("Persatuan Nelayan Kelantan" - PNK) in Tumpat, which forms the anchor company, will invest, manage, and operate the centre with its strategic partners assisting in distribution and marketing of fish sauce for local and international markets. Local fishermen and entrepreneurs in the surrounding area will have the opportunity to benefit from the project by supplying fresh anchovies and pre-fermented fish sauce (Budu) to be further processed into high quality fish sauce through manufacturing arrangements with the anchor company (ECERDC, 2018).

\section{Pasir Mas Halal Park}

Pasir Mas Halal Park, in particular, is located on the Malaysian side of the border crossing between Kota Baru in Thailand and Rantau Panjang in Malaysia. The park consists of an Entrepreneur Business Complex (EBC) which caters for small medium enterprises and also industrial lots for bigger players. It is being developed on a 55 hectare site with a central marketing and processing complex that manufactures food-based products and an incubator centre for micro-enterprises that produce traditional and specialty foods. The centre concentrates on the production of additives and ingredients that have applications ranging from food additives to material inputs for the pharmaceutical industry and health care sector. Its close proximity to the Thailand border offers an opportunity for close synergies between the industries that are located in Narathiwat and other southern provinces.

Thai businesses operating under joint ventures with companies in the Pasir Mas Halal Park can take advantage of its Halmas status, which is an accreditation given to halal park operators who have successfully complied with the requirements and guidelines stipulated under the Halal Development Corporation (HDC) designated Halal Park Development. It is also a mark of excellence for parks that produce high quality halal products. With that accreditation, companies in the park can receive incentives given by the Malaysian authorities (Ministry of International Trade and Industry, 2013). 


\section{Narathiwat Special Economic Zone}

The Malaysian and Thai governments have developed strategies for developing their respective border areas. The ECERDC with the support of Kelantan state government has developed Pasir Halal Park in the Pasir Mas area and made Rantau Panjang as the CrossBorder Tourism Corridor along with Pengkalan Kubor and Bukit Bunga towns. Pengkalan Kubor town is bordered by Tak Bai town (Narathiwat) and Bukit Bunga with Bunga (Kelantan)-Ban Buketa (Narathiwat). In Pengkalan Kubor, the Collection, Processing and Packaging Centre (CPPC) was developed to produce maritime based products for export markets.

The Thailand government has also developed the National Special Economic Zone (NSEZ) in Narathiwat. NSEZ comprises five districts of Narathiwat Province, which is as follows: (i) Muang Narathiwat District including Kok Kian sub-district, (ii) Tak Bai District including Jeh Hay sub-district, (iii) Yee Ngor District including La Harn sub-district, (iv) Wang District including Loh Jood sub-district, and (v) Sg. Kolok District including Sg. Kolok sub-district. Figure 3 shows the location of the NSEZ. Table 7 shows the competencies and opportunities in Narathiwat province.

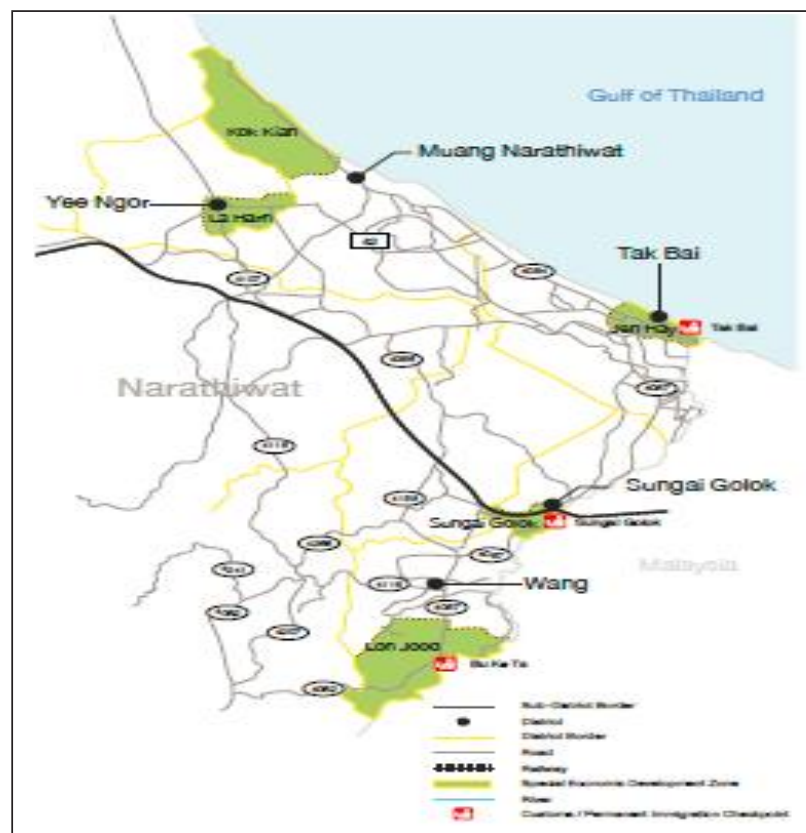

Figure 3. Location of Narathiwat Special Economic Zone.

Source. Thailand, Office of the Board of Investment (August 2015). A Guide to Investment in the Special Economic Development Zones. Bangkok: Board of Investment. 
Table 7

Narathiwat Special Economic Zones

\begin{tabular}{|c|c|c|}
\hline Province & Competencies and Opportunities & Competence Activities \\
\hline Narathiwat & $\begin{array}{l}\text { 1. Three (3) International Border Checkpoints } \\
\text { including Sg. Kolok, Tak Bai and Buketa, } \\
\text { which supports cross-border trade and } \\
\text { tourism between Thailand and Malaysia. } \\
\text { Narathiwat Airport is competent in providing } \\
\text { transportation services and travel for tourists } \\
\text { and investors, both Thai and Malaysian, in } \\
\text { the border area connecting to major cities in } \\
\text { Thailand } \\
\text { 2. Sg. Kolok (Narathiwat) is the final destination } \\
\text { of the Southern rail route from Bangkok- } \\
\text { Sg. Kolok with connecting railway to the } \\
\text { Malaysian railway (Kelantan State), gateway } \\
\text { to Malaysia. If the rail route between } \\
\text { Sg. Kolok and Kelantan State is opened } \\
\text { for service, it will increase the economic } \\
\text { opportunities for Narathiwat Province }\end{array}$ & $\begin{array}{l}\text { 1. Cross-border trade, food } \\
\text { industry and multimodal } \\
\text { transportation } \\
\text { 2. Industrial use of land, } \\
\text { logistic centre, commerce } \\
\text { and research centre } \\
\text { 3. Halal food industry and } \\
\text { establishment of economic } \\
\text { zone in the area of Muang } \\
\text { Narathiwat District and Tak } \\
\text { Bai International Border } \\
\text { Checkpoint, linking the rail } \\
\text { route to Kuala Lumpur, } \\
\text { Malaysia }\end{array}$ \\
\hline & $\begin{array}{l}\text { 3. Raw materials supporting the agriprocessing } \\
\text { industry i.e. rubber, palm oil, and a distinctive } \\
\text { culture for development of Halal food }\end{array}$ & \\
\hline
\end{tabular}

Source.Thailand, Office of the Board of Investment (2015). A Guide to Investment in the Special Economic Development Zones. Bangkok: Board of Investment.

\section{Narathiwat Development Strategy}

Narathiwat Province is a major centre for agricultural production as well as manufacturing. The province is being developed as a centre for halal food production. The Thailand government is encouraging production and export of halal products and foods to Muslim consumers around the world, and there is a large potential for Thailand to expand this industry through collaboration projects with Malaysia and Indonesia, as well as Brunei Darussalam. The Islamic Bank of Thailand has branches in Narathiwat province for funding these and other types of projects, and there are a number of country-wide organisations that can provide support in terms of knowledge and technology, such as the Halal Science Centre at Chulalongkorn University.

The Government's strategic goals for 2015-2018 are (i) to develop production, border trade, local products, tourism, and sports linked to the ASEAN Economic Community (AEC); (ii) 
to develop quality of life base on its "sufficiency economy" approach; and (c) to promote peace in the area.

Specific projects planned for 2015-2018 include: (i) a railway project linking Sg. Kolok to the Malaysian district of Pasir Mas in order to promote Thai-Malaysian tourism; (ii) construction of a highway, bridge, and customs facility linking Takbai and Pengkalan Kubor to replace the car ferry crossing; (iii) Narathiwat airport terminal and runway expansion project to accommodate more traffic; (iv) construction of the Bukit Tal customs office and logistics centre; (v) construction of a Sg. Kolok crossing bridge between $\mathrm{Sg}$. Kolok and Rantau Panjang; (vi) construction of an industrial estate and logistics centre in Khok Krako, Takbai; and (v) construction and operation of an agricultural market.

Development of the Narathiwat Agricultural Market is expected to facilitate trade in agricultural goods and services between Thailand and Malaysia. The total project area is over 50 hectares in Yi-ngo district. There are also a number of projects under the strategic plan to promote agricultural production, non-agricultural industries, and international trade.

\section{Cross Border Special Economic Zone Connectivity}

Until today, there are no industrial linkages between the Special Economic Zone in Sg. Kolok (Narathiwat) and in Pasir Mas (including Rantau Panjang). A linkage industry is an industry which is associated or connected to other industries in such a way that the existence of one is dependent on the other, or it enhances the other's production process. There are two types of industry linkages, namely (i) forward linkages, and (ii) backward linkages. A forward linkage is created when investment in a particular project encourages investment in subsequent stages of production. A backward linkage is created when a project encourages investment in facilities that enable the project to succeed.

Economic relations in Sg. Kolok and Rantau Panjang are based on tourism activities that tourists from Malaysia and Thailand, including international travellers, crossing the border to shop either in the town of Sg. Kolok or Rantau Panjang, especially Rantau Panjang DFZ. Export and import activities between Sg. Kolok and Rantau Panjang are to satisfy the demand in the Narathiwat and Kelantan, Terengganu, and Pahang markets. In addition to economic activity, Sg. Kolok and Pas Mas are still dependent on the retailing and wholesaling industry. Therefore there is no industry linkage either in the form of backward or forward linkage that involves the production process and for the export purpose third countries' market.

In this regard, there is a need to establish an industrial linkage between SEZ in Sg. Kolok and in Pasir Mas with their respective government counterparts providing tax incentives to attract investments to the SEZ (refer to Figure 4). The SEZ industry linkage between $\mathrm{Sg}$. Kolok and Pasir Mas can be forward and backward linkages. This could make Rantau Panjang SEZ as a production platform for export to third world countries, especially in the production of halal products. SEZ in Sg. Kolok and Pasir Mas have comparative advantage 
in agricultural production. Through the industrial linkage between SEZ in Sg. Kolok and Pasir MAS, this will justify the establishment of the Rantau Panjang-Sg. Kolok CBSEZ.

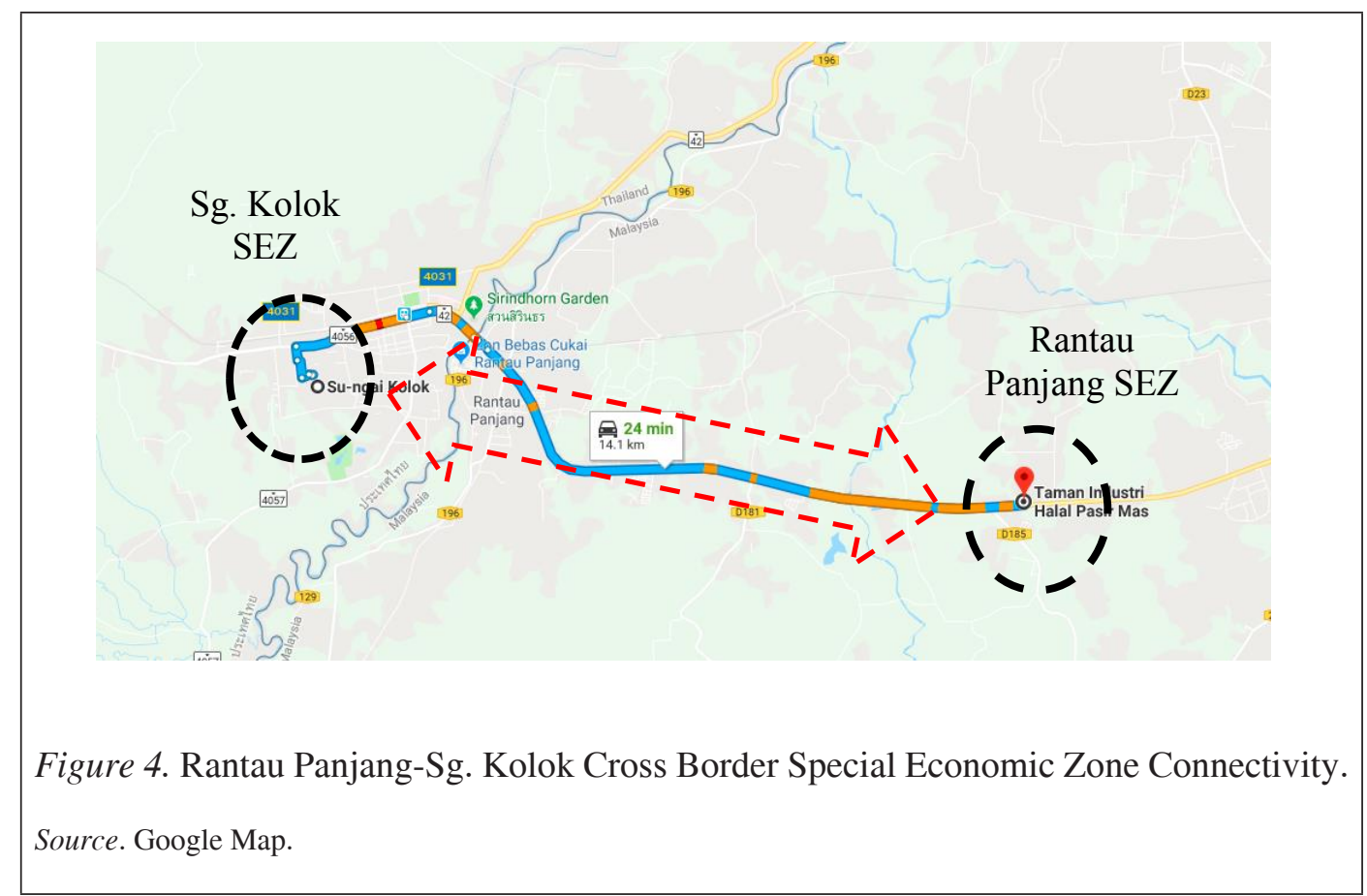

\section{Conclusion}

The complementary comparative advantages and the availability of modern infrastructure and communications at Sg. Kolok SEZ and Rantau Panjang (Pasir Mas) have led to the possible implementation of the Rantau Panjang-Sg. Kolok CBSEZ. Sg. Kolok and Rantau Panjang have received the attention of Thailand and Malaysia under the Joint Development Strategy (JDS) for border areas, ECERDC, and the Asian Development Bank (ADB). In 2015, the Malaysian and Thailand governments have identified cross-border tourism as one of the six areas of potential economic cooperation, as well as the automotive industry, rubber industry in border areas, food security, energy, oil and gas, and tourism (Malaysia Ministry of Foreign Affairs, 2015).

Even though the Narathiwat region is a political conflict zone, the Thai Government has introduced a Blueprint Action Plan on Southern Border Province Development 20122014 and Southern Border Provinces Special Zone Development (SBPSZD) 2009-2012, in order to secure stable conditions in conflict areas to attract incoming investments into the Narathiwat SEZ. The two blueprints focus on raising local income and quality of life, ensuring justice and life and property security, developing human capital and improving 
social service standards, restoring local economies and promoting investments, linking local economies with neighbouring countries, improving legislation and regulations, and enhancing the efficiency of management and delivery systems.

In conclusion, Rantau Panjang-Sg. Kolok CBSEZ has the potential to be developed through industrial linkages between the two SEZs. This will have an impact on economic spill-overs through trade and investment whose economic profit from activity will be crossing the two extreme regions. In the long run, dynamic and large-scale economic activities will generate economic growth of the border regions and benefit for both bordering countries.

\section{Acknowldgement}

The authors like to thank Universiti Utara Malaysia for providing funding to do the study on Program Transformasi Ekonomi Pekan Sempadan Di Persempadanan Malaysia-Indonesial Thailand/Brunei/Ke Arah Pembangunan Ekonoi Lestari Dan Berpendapatan Tinggi (FRGS 12185).

\section{References}

Abdul Rahim Anuar (2015). Rubrik pembangunan pekan sempadan Malaysia-Kalimantan: Tawau-Pulau Nunukan. Journal of Borneo Social Transformation Studies, 1(1).

Abdul Rahim Anuar, Muszafarshah Mohd Mustafa \& Amel Farhat. (2013). Danok-BukitKayu Hitam, twin border towns on the Thailand-Malaysia's border. In Nathalie Fau, Sirivanh Khonthapane, Christian Taillard, (Eds.), Transnational Dynamics in Southeast Asia: The Greater Mekong Subregion and Malacca Straits Economic Corridors (pp. 321-337). Singapore: Institute of Southeast Asian Studies.

Arksey, H., \& O’Malley, L. (2005). Scoping studies: Towards a methodological framework. International Journal of Social Reseach Methodology, 8(1), 19-32.

Arnold, D. (2010). Administration, border zones and spatial practices in the Mekong subregion (Unpublished doctoral dissertation). University of North Carolina, Chapel Hill..

Asian Development Bank. (1998). Economic cooperation in the Greater Mekong Subregion: An overview. Manila: Asian Development Bank.

Asian Development Bank. (2002). Building on success: A strategic framework for the next ten years of the greater Mekong subregion economic cooperation program. Manila: Asian Development Bank.

Asian Development Bank. (2007). Mid-term review of the greater Mekong sub-region strategic framework 2002-2012. Manila: Asian Development Bank.

Choen, K. (2008). Cross-border trade and commerce in Thailand: Policy implications for establishing special border economic zones (Unpublished doctoral thesis). Asian Institute of Technology, Bangkok, Thailand.

ECERDC. (2013). An investment guide to the ECER. East Coast Economic Region Developement Council. Kuala Lumpur. Retrieved from http://www.ecerdc.com.my 
ECERDC. (2018): Economic Clusters. Collection, Processing and Packaging Centre in Pengkalan Kubor, Kelantan. East Coast Economic Region Developement Council. Kuala Lumpur. Retrieved from http://www.ecerdc.com.my/en/economic_post/ collection-processing-and-packaging-centre-in-pengkalan-kubor-kelantan/

Escalada, M. (2009). Scoping study. Retrived from ricehoppers.net/wp-content/ uploads/2009/10/tools-scoping study1.pdf.

Fauzi, H., Norehan, A., Husin, A., \& Selamah, M. (2012). Aktiviti ekonomi sempadan di perairan Sg. Golok-Rantau Panjang: Isu dan cabaran. Kertas kerja yang dibentangkan di Persidangan Kebangsaan Ekonomi Malaysia. Bangi: UKM.

Kelantan State Economic Development Corporation. (2018). Industrial estate in Kelantan. PKINK. Kota Bharu. Retrieved from http://invest.kelantan.my/index.php/ms/

Kelantan State Tourism Information Centre. (2000). Tourism Data 1984-2000. Kelantan State Tourism Information Center. Kota Bharu. Retrieved from http://kelantan.gov. my/stourism.html.

Lord, M., \& Tangtrongita, P. (2014). Special border economic zone in the IndonesiaMalaysia-Thailand Growth Triangle (IMT-GT). MPRA Paper No. 61060.

Maneepong, C., \& Wu, C. T. (2004). Comparative Borderland Development in Thailand. ASEAN Economic Bulletin, 21(3), 133-166.

Ministry of Foreign Affairs, Malaysia. (2015, October 20). Press release:13th Joint Commission for Bilateral Cooperation (JCM) and 4th Joint Development Strategy for Border Areas (JDS) between Malaysia and the Kingdom of Thailand. Kuala Lumpur, 21-22 October. Ministry of Foreign Affairs, Malaysia. Retrieved from https://www.kln.gov.my/archive/content.php?t=3\&articleId=5682266 .

Ministry of International Trade and Industry. (2013, April 24). Halal Hub. Kuala Lumpur, Government of Malaysia. Retrieved from http://www.miti.gov.my/cms/content. jsp?id=com.tms.cms.section.Section_8ab65e4b-7f000010-72f772f7-ce3196c6.

New Straits Times. (2017, February 7). Tok Bali - Kelantan's new growth area for investment. New Straits Times. Retrieved from https://www.nst.com.my/news/2017/02/210297/ tok-bali-kelantans-new-growth-area-investment

Pasir Mas District Office, Kelantan. (2008). Pasir Mas Local Development Plan 2008 2020. Pasir Mas: MDPM.

Pasir Mas District Office, Kelantan. (2018). Rantau Panjang Duty Free Zone. Pasir Mas: MDPM.

Royal Malaysian Customs Department. (2018). Duty Free Shops. Putrajaya, Royal Malaysian Customs Department. Putrajaya. Retrived from http://www.customs. gov.my/en/ip/Pages/ip_dfs.aspx

Thailand, Office of the Board of Investment. (2015). A guide to investment in the special economic development zones. Bangkok, Board of Investment.

Tsuneishi, T. (2008). Development of border economic zones in Thailand: Expansion of border trade and formation of border economic zones, IDE Discussion Paper, 153. Tokyo: Institute Developing Economy.

UPEN (2018). Basic Economic Data 2015-16. Kota Bharu: Unit Perancang Ekonomi Negeri Kelantan.

World Bank. (2008). Special economic zones: Performance, lessons learned, and implications for zone development. Washington: World Bank. 